\title{
PENERAPAN METODE DEMONSTRASI UNTUK MENINGKATKAN \\ PRESTASI PENDIDIKAN AGAMA BUDDHA SISWA KELAS IV \\ DI SEKOLAH DASAR NEGERI HARGOROJO KECAMATAN BAGELEN \\ KABUPATEN PURWOREJO
}

\author{
Sukarman, Sujiono, Hesti Sadtyadi \\ STABN Raden Wijaya \\ putravendiro0990@gmail.com,sujionoradenwijaya@gmail.com,15hestisadtyadi@gmail.com
}

\begin{abstract}
This research aims to know the effect of demonstration method to improve students' activity and learning achievement. This research is a classroom action research (CAR). This research focuses on 7 students. Instruments that used are observation sheets, interview guide and test. The data analysis uses descriptive qualitative data analysis and quantitative data analysis. The result of the research shows students' activity and learning achievement has improved after learning process by using demonstration method. Students'learning achievement before implementing demonstration method is 69,14 and it becomes 74 on the first learning cycle. Therefore students' learning achievement improves $4,86 \%$. Then on the second learning cycle students' learning achievement improves from 74 becomes 89 . It improves from 42,86\% becomes $100 \%$. It can be concluded that the learning process by using demonstration method can improve students' learning achievement of Buddhist religious education at Hargorojo state elementary school.
\end{abstract}

Keywords: Buddhist religious education, demonstration method, learning achievement.

\begin{abstract}
ABSTRAK
Penelitian ini bertujuan untuk mengetahui pengaruh metode demonstrasi untuk meningkatan keaktifan dan prestasi belajar siswa. Merupakan jenis Penelitian Tindakan Siswa (PTK). Fokus penelitian ini adalah siswa kelas IV yang berjumlah 7 siswa. Instrumen penelitian menggunakan lembar observasi Pedoman wawancara dan soal tes. Penelitian ini menggunakan teknis analisis data deskriptif kulitatif dan deskriptif kuantitatif. Hasil penelitian menunjukan keaktifan dan prestasi belajar siswa mengalami peningkatan setelah proses pembelajaran menggunakan metode demonstrasi. Prestasi belajar siswa dari kondisi awal nilai rata-rata sebesar 69,14 menjadi 74 pada pembelajaran siklus I sehingga prestasi belajar siswa mengalami peningkatan sebesar $4,86 \%$. Selanjutnya pada pembelajaran siklus II prestasi belajar siswa mengalami peningkatan dari $42,86 \%$ menjadi $100 \%$. Hasil penelitian ini menunjukan proses pembelajaran dengan menggunakan metode demonstrasi dapat meningkatkan prestasi belajar siswa kelas IV di SD N Hargorojo Kecamatan Kabupaten Purworejo.
\end{abstract}

Kata kunci: metode demonstrasi, pendidikan agama Buddha, prestasi belajar, 


\section{PENDAHULUAN}

Pendidikan yang berkualitas tidak terlepas dari peran guru. Guru berperan penting dalam membangun karakter siswa melalui materi pelajaran sekolah. Guru yang kompeten akan mampu menciptakan pembelajaran yang berkualitas dan menghasilkan prestasi belajar yang baik untuk siswa. Proses belajar mengajar yang berkualitas adalah ketika guru dapat menyampaikan materi secara baik dan dapat dipahami oleh siswa. Prestasi baik yang diharapkan adalah siswa dapat memahami materi yang disampaikan dan mampu mengaktualisasikannya dalam kehidupan seharihari di masyarakat. Prestasi tersebut akan terlihat berupa pengetahuan, sikap maupun perbuatan siswa, sehingga siswa memiliki nilai yang baik dari segi kognitif, afektif, maupun psikomotorik.

Muhibbin Syah (2004: p.141), “prestasi belajar adalah setiap macam kegiatan belajar menghasilkan sesuatu perubahan yang khas yaitu hasil belajar". Prestasi belajar dapat diukur dan dievaluasi langsung dengan tes dan hasil inilah yang disebut dengan prestasi belajar. Prestasi belajar merupakan hasil belajar yang meliputi perubahan tingkah laku,perubahan sikap, perubahan kebiasaan, perubahan kualitas penguasaannya. Hasil perubahan tersebut diwujudkan dengan nilai atau skor. (Winkel, 2005: p.532

Menurut Sugihartono, dkk. (2007: p.7677), faktor-faktor yang mempengaruhi prestasi belajar siswa dapat digolongkan menjadi 3 (tiga) bagian yaitu :

1) Faktor Intern, yaitu faktor yang berasal dari dalam diri siswa meliputi: kematangan, kecerdasan/Intelegensi, latihan dan ulangan, motivasi, dan sifat-sifat pribadi seseorang.
2) Faktor Ekstern, yaitu faktor yang berasal dari luar diri siswa atau yang sering dikenal dengan faktor sosial meliputi: keadaan keluarga, guru dan cara mengajar, alat-alat pelajaran, motivasi sosial, lingkungan dan kesempatan

3) Faktor Situasiona meliputi: keadaan politik ekonomis, keadaan waktu yang mencakup jumlah hari dan jumlah jam setiap hari yang tersedia bagi kegiatan belajar mengajar dan keadaan musim iklim kerap menciptakan kondisi psikis dan kondisi fisik pada siswa dan guru yang kurang menguntungkan

Hasil wawancara lanjutan yang dilakukan peneliti dengan siswa kelas IV yang beragama Buddha di Sekolah Dasar Negeri Hargorojo diperoleh informasi bahwa dalam proses pembelajaran guru hanya memberikan banyak tugas kepada siswa. Selain itu, guru mendominasi pembelajaran dengan metode ceramah dan guru seringkali hanya menyuruh siswa untuk mencatat. Peran guru sebagai fasilitator dalam proses pembelajaran bukan berarti hanya menyediakan materi, namun mutlak untuk mentranformasikan ilmu pengetahuan kepada siswa. Pemilihan metode pembelajaran sebaiknya disesuaikan dengan tujuan pembelajaran yang akan dicapai. Penggunaan metode pembelajaran yang bervariasi dan korelasional sangat membantu siswa dalam memahami mata pelajaran yang disampaikan. Siswa lebih aktif dan responsif ketika pembelajaran berlangsung. Metode pembelajaran yang monoton dapat membuat siswa bosan dan kurang antusias untuk mengikuti pembelajaran di kelas. Oleh karena itu, kemampuan dan ketrampilan seorang guru sangat dibutuhkan untuk mendesain pelaksanaan pembelajaran di kelas.

Sebagai salah satu komponen dalam 
proses pembelajaran, metode menempati peranan yang tidak kalah pentingnya bila dibandingkan dengan komponen lainnya dalam kegiatan belajar mengajar pendidikan agama Buddha. Penggunaan metode terkadang guru harus menyesuikan dengan kondisi dan suasana kelas. Jumlah siswa mempengaruhi penggunaan metode pembelajaran. Guru dalam menentukan pemilihan metode Tujuan intruksional. Perumusan tujuan guru perlu merumuskannya dengan jelas dan dapat diukur.

Nana Sudjana (2010: p.83) mengemukakan metode demonstrasi adalah suatu metode mengajar memperlihatkan bagaimana jalannya suatu proses terjadinya sesuatu. Oleh karena itu metode demonstrasi merupakan metode mengajar yang sangat efektif, sebab membantu para peserta didik untuk mencari jawaban dengan usaha sendiri berdasarkan fakta yang dilihat. Metode demonstrasi adalah cara penyajian materi pelajaran melalui peragaan atau pertunjukan kepada siswa mengenai suatu proses, situasi atau gejala tertentu yang dipelajari, baik pada objek yang sebenarnya ataupun melalui tiruan. Metode demonstrasi sering disertai dengan penjelasan lisan (Udin, 2001: p.217).

Langkah-langkah dalam menggunakan metode demonstrasi menurut Fathurrohman dan Sutikno (2001: p. 61), yang perlu dilakukan dalam metode demonstrasi adalah sebagai berikut:

a. Tahap persiapan

Pada tahap persiapan ini ada beberapa hal yang harus dilakukan oleh seorang guru, yaitu:

1) Merumuskan tujuan yang akan dicapai. Tujuan ini meliputi beberapa aspek seperti pengetahuan, sikap dan ketrampilan.

2) Mempersiapkan garis besar langkahlangkah demonstrasi yang akan dilakukan.
Garis besar langkahlangkah demonstrasi diperlukan sebagai panduan untuk melakukan demonstrasi.

3) Melakukan uji coba demonstrasi dengan menggunakan alat-alat yang dibutuhkan. Uji coba ini dilakukan untuk menghindari kegagalan dalam demonstrasi.

\section{b. Tahap pelaksanaan}

1. Langkah pembukaan

Dalam tahap pembukaan metode demonstrasi ini ada beberapa hal yang perlu diperhatikan:

a) Mengatur tempat duduk yang memungkinkan semua murid dapat memperhatikan dengan jelas apa yang didemonstrasikan.

b) Mengemukakan tujuan yang hendak dicapai oleh murid,

c) Mengemukakan tugas-tugas yang harus dilakukan oleh murid.

2. Langkah pelaksanaan demonstrasi

a) Guru memulai demonstrasi dengan kegiatan-kegiatan yang bisa merangsang murid untuk berfikir.

b) Menciptakan suasana yang menyejukkan dan menghindari suasana yang menegangkan.

c) Meyakinkan murid untuk mengikuti jalannya demonstrasi dengan memperhatikan reaksi murid.

d) Memberikan kesempatan murid secara aktif untuk berfikir lebih lanjut sesuai dengan apa yang dilihat dari proses demonstrasi tersebut.

\section{c. Langkah penutup}

Dalam mengakhiri proses belajar mengajar yang menggunakan metode demonstrasi hendaknya guru memberikan tugas-tugas 
tertentu yang ada kaitannya dengan demonstrasi yang telah dilakukan. Hal ini perlu dilakukan, untuk mengetahui apakah demonstrasi yang dilakukan oleh guru dapat dipahami oleh murid atau tidak. Selain guru memeberikan tugas, guru bisa melakukan evaluasi kepada murid untuk memperagakan apa yang telah didemonstrasikan oleh guru.

Berdasarkan permasalahan di atas dan mengingat pentingnya penerapan metode demonstrasi dalam pembelajaran pendidikan agama Buddha maka peneliti tertarik melakukan penelitian tindakan dengan judul "Penerapan metode demonstrasi untuk meningkatkan prestasi pendidikan agama Buddha siswa kelas IV Di Sekolah Dasar Negeri Hargorojo kecamatan Bagelen Kabupaten Purworejo".

Adapun tujuan penelitian ini adalah: (1) Meningkatkan keaktifan belajar siswa kelas IV Sekolah Dasar Negeri Hargorojo Kecamatan Bagelen Kabupaten Purworejo melalui penerapan metode demonstrasi; (2) Meningkatkan prestasi belajar pendidikan agama Buddha siswa kelas IV Sekolah Dasar Negeri Hargorojo Kecamatan Bagelen Kabupaten Purworejo melalui penerapan metode demonstrasi.

\section{METODE PENELITIAN}

Jenis penelitian ini yang digunakan pada penelitian ini adalah penelitian tindakan kelas (classroom action research). Penelitian tindakan kelas adalah penelitian tindakan (action research )yang dilakukan dengan tujuan memperbaiki mutu praktik pembelajaran dikelasnya (Suhardjono, 2008: p.58). Penelitian tindakan kelas menurut Mulyasa (2011: p.112) ada empat tahap pelaksanaan pemberian tindakan.
Tahapan pemberian tindakannya adalah sebagai berikut: tahap perencanaan (Planning), pelaksanaan (Acting), observasi (Observing), dan refleksi (Reflecting.

Penelitian dilakukan di SD N Hargorojo Kecamatan Bagelen Kabupaten Purworejo pada bulan Agustus-Oktober 2015. Fokus penelitian ini adalah siswa kelas IV yang berjumlah 7 siswa, yaitu 5 siswa perempuan dan 2 siswa laki-laki.

Penelitian ini dilakukan dalam dua siklus hingga motivasi dan prestasi belajar siswa meningkat. Setiap siklus dilaksanakan sesuai dengan perubahan yang terjadi. Hal ini ditentukan atas dasar refleksi pada pada siklus-siklus penelitian. Agar kemampuan awal siswa dapat diketahui maka diadakan tes pra tindakan yang berfungsi sebagai evaluasi awal.

Dalam penelitian ini ada tiga teknik pengumpulan data yang digunakan oleh peneliti guna mendapat informasi penelitian yaitu: observasi, wawancara dan tes. Penelitian ini menggunakan teknis analisis data deskriptif kulitatif dan deskriptif kuantitatif. Analisis deskriptif kualitatif yaitu analisis data yang berupa informasi yang berbentuk kalimat, sedangkan analisis deskriptif kuantitatif adalah analisis data yang berupa nilai belajar siswa.

\section{PEMBAHASAN}

Penelitian tindakan kelas yang dilakukan di SD N Hargorejo telah dilaksanakan sebanyak 2 siklus. Penerapan metode demonstrasi pada penelitian tindakan kelas adalah sebagai berikut: Guru pendidikan agama Buddha dan peneliti memasuki kelas untuk pembelajaran pendidikan agama Buddha. Kegiatan pembelajaran diawali dengan melafalkan parita namakaragatha secara terpimpin, yang dalam hal ini dipimpin oleh 
salahsatu siswa. Setelah namakaragatha selesai dilafalkan, selanjutnya guru menjelaskan topik, tujuan dan hasil belajar yang diharapkan, menjelaskan pokok-pokok kegiatan yang harus dilakukan oleh siswa, serta menjelaskan pentingnya topik dan kegiatan pembelajaran, kemudian juga guru memberikan sumber mengenai materi Pertolongan Sejati.

Memasuki materi pembelajaran, guru menjelaskan materi yang akan dibahas pada pertemuan ini. Guru menjelaskan hal-hal yang akan dilakukan oleh siswa. Guru menjelaskan materi mengenai pertolongan sejati sebagai pengantar materi pembelajaran. Guru menjelaskan mengenai orang yang pantas untuk ditolong dan cara-cara memberikan pertolongan sejati. Pada pembelajaran ini, demonstrasi yang dilakukan adalah demonstrasi mengenai merawat orang tua yang sakit. Dimana diperankan oleh guru dan salahsatu siswa. Salahsatu siswa bernama Rosita maju kedepan untuk membantu guru mendemonstrasikan merawat orang tua yang sakit.

Guru sebagai orang tua kemudian siswa berperan sebagai sang anak. Kemudian siswa yang lain memperhatikan dan mencatat mengenai demonstrasi yang dilakukan oleh guru dan siswa. Kemudian guru melakukan demonstrasi mengenai merawat orang tua dengan siswa. Siswa yang berperan sebagai anak mulai melakukan demonstrasi dengan guru mengenai hal-hal yang dilakukan saat orang tua sakit. Setelah demonstrasi dilaksanakan, siswa yang lain mencatat hasil demonstrasi yang dilakukan kemudian mengumpulkan hasil demonstrasi yang dilakukan dalam tema merawat orang tua yang sedang sakit dimana siswa berperan sebagai anak dan guru sebagai orang tua.

Dibawah ini akan diuraikan mengenai pembandingan hasil-hasil penelitian tindakan kelas yang dilaksanakan di Sekolah Dasar Negeri Hargorejo, kecamatan Bagelen kabupaten Purworejo. Hal yang akan diuraikan adalah mengenai ketuntasan belajar, kemampuan guru dan aktifitas siswa.

\section{a) Ketuntasan Belajar}

Melalui hasil penelitian ini menunjukkan bahwa penerapan metode demonstrasi dalam pembelajaran berimplikasi positif dalam meningkatkan hasil belajar siswa dan presstasi belajar. Hal ini dapat dilihat dari semakin mantapnya pemahaman siswa terhadap materi yang disampaikan guru. Ketuntasan belajar meningkat dari pra siklus, siklus I dan siklus II, yaitu masing-masing $0 \%, 42,86 \%$ dan $100 \%$. Pada siklus II ketuntasan belajar telah tercapai.

\section{b) Kemampuan Guru dalam Mengelola Pembelajaran}

Berdasarkan analisis data, diperoleh aktivitas siswa dalam proses belajar mengajar dengan menerapkan metode demonstrasi dalam setiap siklus mengalami peningkatan. Hal ini menggambarkan bahwa kemampuan guru dalam mengelola pembelajaran sudah baik, sehingga dampak positifnya terhadap hasil belajar siswa cukup signifikan. Hal ini juga dapat dilihat dari meningkatnya nilai rata-rata siswa pada setiap siklus yang mengalami peningkatan.

\section{c) Aktifitas Siswa dalam Pembelajaran}

Berdasarkan analisis data, diperoleh aktivitas siswa dalam proses pembelajaran agama Buddha pada Kompetensi Dasar Mempraktikkan materi dengan menggunakan metode demonstrasi yang paling dominan adalah antusiasme dan semangat siswa dalam mengikuti proses pembelajaran dan hidupnya 
suasana kelas. Dengan demikian, maka dapat dikatakan bahwa aktivitas siswa dapat dikategorikan aktif partisipatif. Sedangkan guru selama pembeajaran telah melaksanakan langkah-langkah kegiatan belajar mengajar sesuai dengan rencana yang telah ditetapkan dengan mengkombinasikan model pengajaran langsung dan kontekstual dengan pendekatan pada penerapan metode demonstrasi.

\section{KESIMPULAN}

Berdasarkan hasil penelitian yang dilaksanakan di SDN Hargorojo Kecamatan Bagelen Kabupaten Purworejo dapat disimpulkan bahwa penelitian tindakan siswa dapat meningkatkan keaktifan dan prestasi belajar siswa dengan menerapkan metode pembelajaran demonstrasi pada mata pelajaran pendidikan agama Buddha mata pelajaran pertolongan sejati. Saat pembelajaran siswa terlihat lebih aktif dan antusias dan juga nampak lebih semangat dalam belajar. Hal ini dapat dilihat berdasarkan tes siswa pada saat penelitian dilaksanakan di SD $\mathrm{N}$ hargorojo. Prestasi belajar siswa dari kondisi awal nilai rata-rata sebesar 69,14 menjadi 74 pada pembelajaran siklus I sehinga prestasi belajar siswa mengalami peningkatan sebesar 4,86\%. Selanjutnya pada pembelajaran siklus II prestasi belajar siswa mengalami peningkatan nilai ratarata dari 74 menjadi 89 sehingga meningkat kembali dari $42,86 \%$ menjadi $100 \%$. Oleh karena itu penelitian tindakan kelas dengan judul upaya meningkatkan prestasi belajar siswa beragama Buddha dengan penerapan model demonstrasi di SDN Hargorojo Kecamatan Bagelen Kabupaten Purworejo memperoleh hasil yang memuaskan dan dapat meningkatkan prestasi belajar siswa.

\section{DAFTAR PUSTAKA}

Mulyasa. (2011). Penelitian Tindakan Kelas. PT Remaja Rosdakarya: Bandung.

Pupuh Fathurrohman \& M. Sobry Sutikno. (2007). Strategi Belajar Mengajar melalui Penanaman Konsep Umum dan Islami. Bandung: Rafika Aditama.

Sudjana, N. (2005). Dasar-dasar proses belajar mengajar. Bandung: sinar baru algesindo.

Syah, M (2006). Psikologi Pendidikan dengan Pendekatan Baru. Bandung: Remaja Rosda Karya

Udin, S. (2001). Model-model Pembelajaran Inovatif. Jakarta Pusat: Direktorat Jenderal Pendidikan Tinggi Departemen Pendidikan Nasional.

Winkel, W.S. (2005). Psikologi Pengajaran. Yogyakarta : Media Abadi. 